\title{
Climate, soil and tree flora relationships in forests in the state of São Paulo, southeastern Brasil ${ }^{1}$
}

\author{
ROSELI BUZANELLI TORRES ${ }^{2}$, FERNANDO ROBERTO MARTINS ${ }^{3} \mathrm{e}$ \\ LUIZA SUMIKO KINOSHITA ${ }^{3}$
}

(recebido em 09/03/95; aceito em 27/09/96)

\begin{abstract}
Climate, soil and tree flora relationships in forests in the state of São Paulo, southteastern Brasil). With the aim of verifying possible influences of abiotic features on the spatial distribution of forest tree species and families, thirteen surveys in the state of São Paulo were selected, representing different conditions (localization at the extreme coordenates and altitudes, succesional stages, surveying methods). By applying Jaccard's Index to the binary matrices of 806 synonymized specific binomina and 79 families (Cronquist's system) phenograms were constructed using the method of the unweighted pair grouping by mathematical average (UPGMA). The species formed two floristic blocks: hygrophyllous (yearly rainfall greater than $2000 \mathrm{~mm}$ without dry season) and mesophyllous (yearly rainfall about $1400 \mathrm{~mm}$ with variable dry season). The latter was divided in two other groups: the high-altitudinal (median altitudes higher than $750 \mathrm{~m}$, frost average frequency greater than 3 days/year) and low-altitudinal. Both mesophyllous floristic blocks were subdivided according to soil conditions (texture, eutrophism, acid or allic dystrophism, iron content). At the family level the relations were weak, but also showed the soil nutritional status as a possible constraint to the spatial partition of families.
\end{abstract}

RESUMO - (Relações entre clima, solo e flora arbórea em florestas no estado de São Paulo, Brasil sudeste). Com o objetivo de verificar possíveis influências de fatores abióticos sobre a repartição espacial de espécies e famílias arbóreas, treze levantamentos no estado de São Paulo foram selecionados, representando diferentes condições (localização nos extremos de coordenadas e altitudes, estádios sucessionais, métodos de levantamento). Aplicou-se o índice de Jaccard a uma matriz binária de 806 binômios específicos sinonimizados e 79 famílias (sistema de Cronquist). Foram construídos fenogramas usando o método de pareamento por média matemática não ponderada (UPGMA). As espécies formaram dois blocos florísticos: o higrófilo (precipitação total anual média maior que $2000 \mathrm{~mm}$ sem estação seca) e o mesófilo (precipitação total anual média ao redor de $1400 \mathrm{~mm}$ com estação seca variável). O bloco mesófilo dividiu-se em dois grupos: o alto-altitudinal (altitude mediana maior que $750 \mathrm{~m}$, frequiência média de geadas maior que três dias/ano) e o baixo-altitudinal. Ambos os grupos do bloco mesófilo subdividiram-se de acordo com parâmetros do solo (textura, eutrofismo, distrofismo ácido ou álico, teor de ferro). No nível de família as relações foram frouxas, mas também indicaram o status nutricional do solo como uma possível influência na repartição espacial

Key words - Tropical forests, tree flora, soil, climate, soil thermohydric regimes

\section{Introduction}

The first attempt to classify Brazilian vegetation was that of Martius (1840) who used names of mythological nymphs ascribed to major features of the landscapes. His system was a mixture of features refering to natural botanical regions including both physiognomy and flora as well as environment. He recognized five botanical provinces: Naiads (nymphs who presided over springs, rivers, and lakes) refering to the Amazonian region; Oreads (presided over mountains and grottoes) refering to the "cerrado" region; Dryads (forests), to eastern

1. From the Master thesis of the first author Curso de Pós-graduação em Biologia Vegetal, IB, Unicamp.

2. Seção de Botânica Econômica, Instituto Agronômico, Caixa Postal 28, 13001-970 Campinas, SP, Brasil.

3 Departamento de Botânica, Instituto de Biologia, Universidade Estadual de Campinas, Caixa Postal 6109, 13081-970 Campinas, SP, Brasil. forests south of Amazonia; Hamadriads (mortal nymphs dwelling in trees, being born, living and dying in them), to the "caatinga" thorn-woodland/ shrubland region; and Napaeae (glens), to the southest grassland region. Martius's (1840) system was used as the basis for almost all the subsequent classification systems (Ferri 1980), which have sometimes stressed floristics (e.g. Sampaio 1945), sometimes physiognomy (such as Azevedo 1950), sometimes abiotic features (like Campos 1912). However, none of these systems can be considered fully satisfactory, especially when one takes into account the huge surface extension of Brazil, the great heterogeneity of its landscapes, the lack of knowledge on most of its flora, the range of physiognomic variations in the same vegetation compartment, etc. One of the main critiques of these systems is the lack of coherence, for a single system may classify vegetation of different types emphasizying features of different natures. 
Moreover, these classifications are inadequate to establish relationships among the floras, between species and abiotic factors or to discuss possible origins. A prospective, sistematic, integrated viewpoint is still lacking.

The situation of the phytogeography in the state of São Paulo is not different. When compared to other states of the south and southeastern regions of Brazil, the state of São Paulo is the least studied concerning vegetation. Loefgren (1898) adapted Martius's (1840) system for the state of São Paulo. He recognized two floristic-vegetational series, the dryadic (forest vegetation and all its successional seres) and the oreadic ("cerrado" and all its physiognomic variations). Eiten (1970) developed Loefgren's (1898) viewpoint, and presented three floristic-vegetational series: the dryadic, covering about $80 \%$ of the state total area with the subseries forest, coastal plain, and mangrove; the oreadic, covering about $18 \%$ of the state total area; and the napaeadic, with the subseries forest and grassland. The forest subseries of the napaeadic series included Araucaria and Podocarpus forests and all the remaining south broadleaf forests. All these types of vegetation could be in a primary or secondary successional stage. These systems emphasized floristics. However, neither Loefgren (1898) nor Eiten (1970) presented any map or more detailed floristic or physiognomic descriptions which could allow one to distinguish the series and subseries. Chiarini \& Coelho (1969) presented a map of the main vegetation types based on aerial photographs, distinguishing littoral vegetation, humid tropical broadleaf forest of slopes, Araucaria forest, Araucaria-Podocarpus mixed forest, high-altitude subtropical forest, tropical broadleaf forest, semideciduous tropical broadleaf forest, "cerradão" (forest-like "cerrado"), "cerrado", and "campo" (grassland). Information gathered from fields other than aerial photographs is still lacking to corroborate or modify this division.

Nevertheless, many quantitative and floristic surveys of Paulian forests were already made, thus representing a considerable volume of data, although not yet enough for deep analysis (Martins 1989, 1991). Such data can, and should, be sistematized in order to provide the construction of working hypotheses which could guide future resarch, sinthesize sparse knowledge, and comprehend several fields of the environmental sciences. Besides, such sistematization could underpin, through a coherent viewpoint, the construction of a system of phytogeographic classification of forests of the state of São Paulo. The main objective of this paper was to present a working hypothesis about the spatial repartition of forest tree species in the state of São Paulo by means of a multivariate classification, considering the possible influence of climate, relief, and soil, and comparing it with the divisions proposed by Chiarini \& Coelho (1969).

\section{Material and methods}

The comparison among the forests was made at the level of tree species and families, but the scandent shrubs Dasyphyllum brasiliense (Spreng.) Cabr., D. flagellare (Casar.) Cabr., Dalbergia frutescens (Vell.) Britton and Strychnos brasiliensis (Spreng.) Mart. were also included because they were listed in many surveys. Undetermined taxa were included in the comparison, having been considered exclusive of the locality of their occurrence. All floristic lists were submitted to synnonimization from recent taxonomical reviews. The samples were chosen in order to include the extreme latitudinal, longitudinal and altitudinal points, be present in all the major geomorphological compartments in the state of São Paulo, show different successional status, represent the most different surveying methods, and have the greatest differences in the number of species surveyed. This was an intentional inclusion of noise (Gauch 1982) in the analises, for if a coherent pattern could arise in spite of the noise, it could be considered a fairly enough strong indication of relationships. Only one riparian forest (Morro do Diabo State Reserve) was included, all the others being non-floodable forests. Most samples are fragments representing primary forests with different degrees of disturbance (from strongly to very weakly disturbed) but one is a thirty-year old secondary forest (Angatuba).

Jaccard's Index was used as a similarity measure, after Pielou's (1984) recommendation: it is the oldest one used by ecologists, it is the simplest one, and its figures are read directly in percent, thus having an easy interpretation. Silva $\&$ Shepherd (1986) also used Jaccard's Index to compare floristic similarity of some Brazilian forests based on presence/absence of genera. Paulian forest data were used in the binary form, i.e., each sample (survey) was compared to each one of all the others, and each species or family was considered present or absent. Jaccard's Index (J) considers both the number of co-occurrences (a) and the number of exclusive occurrences in one sample (b) and in the other (c), but disregards the number of co-absences:

$$
\mathrm{J}=100 \mathrm{a} /(\mathrm{a}+\mathrm{b}+\mathrm{c})
$$

The species similarity matrix was calculated by means of a software developped by dr C. L. Lucchesi (IMECC/UNICAMP) specially for this study. The family similarity matrix was calculated by means of a software developped by the second author. A cluster analysis was used to establish the relations among the similarity figures (Clifford \& Stephenson 1975). The phenogram was constructed by means of the method of the unweighted pair grouping of mathematical average UPGMA (Gauch 1982). Species and families were chosen for this analysis because they represent the most natural taxonomic categories 
(Heywood 1967). Delimitation of families followed the classification of Cronquist (1981).

Table 1 shows the samples analysed in this paper, their location in the municipalities, the authors who surveyed them, and the methods employed. The localization of the samples is shown by figure 1 , with a map also showing the geomorphological compartmentation of the state of São Paulo in which each compartment was formed in different geological ages (Almeida 1964) Table 2 lists the main features of each sample. Data were extracted from the papers in table 1 . When the papers did not supply the infomation requested other papers were consulted. The altitude figures in table 2 refer to the median point of the altitudinal variation above the sea level in the sample. The conversion of the Brazilian taxonomic soil nomenclature to other systems is problematic and hardly feasible (Camargo et al.1987), and so it is maintained in table 2 .

\section{Results}

Figure 2 shows the species similarity dendrogram. It is possible to distinguish several groups whose similarities range from about $6 \%$ to about $37 \%$, thus showing great differences. Figure 3 shows the family similarity dendrogram. It does not furnish a distinction of groups as good as that of figure 2 , the similarity values ranging from about $42 \%$ to about $78 \%$. The samples are not grouped in figure 3 in the same way they are in figure 2. However, some groups are persistent, such as Campinas-Rio Claro, Bauru-Praxedes, Angatuba-Japi, São José dos Campos-Instituto de Botânica, at the higher similarity levels.

The species similarity (figure 2) shows that the formation of the two groups at the level of about $6 \%$ may be explained by the climate: Ubatuba receives an average total of $2377 \mathrm{~mm}$ of rain per year, and there is neither the characterization of a dry season nor frost occurrence, while the other localities receive a range between 1100 and $1526 \mathrm{~mm}$ of rain per year, show a variable drought period (1 to 6 dry

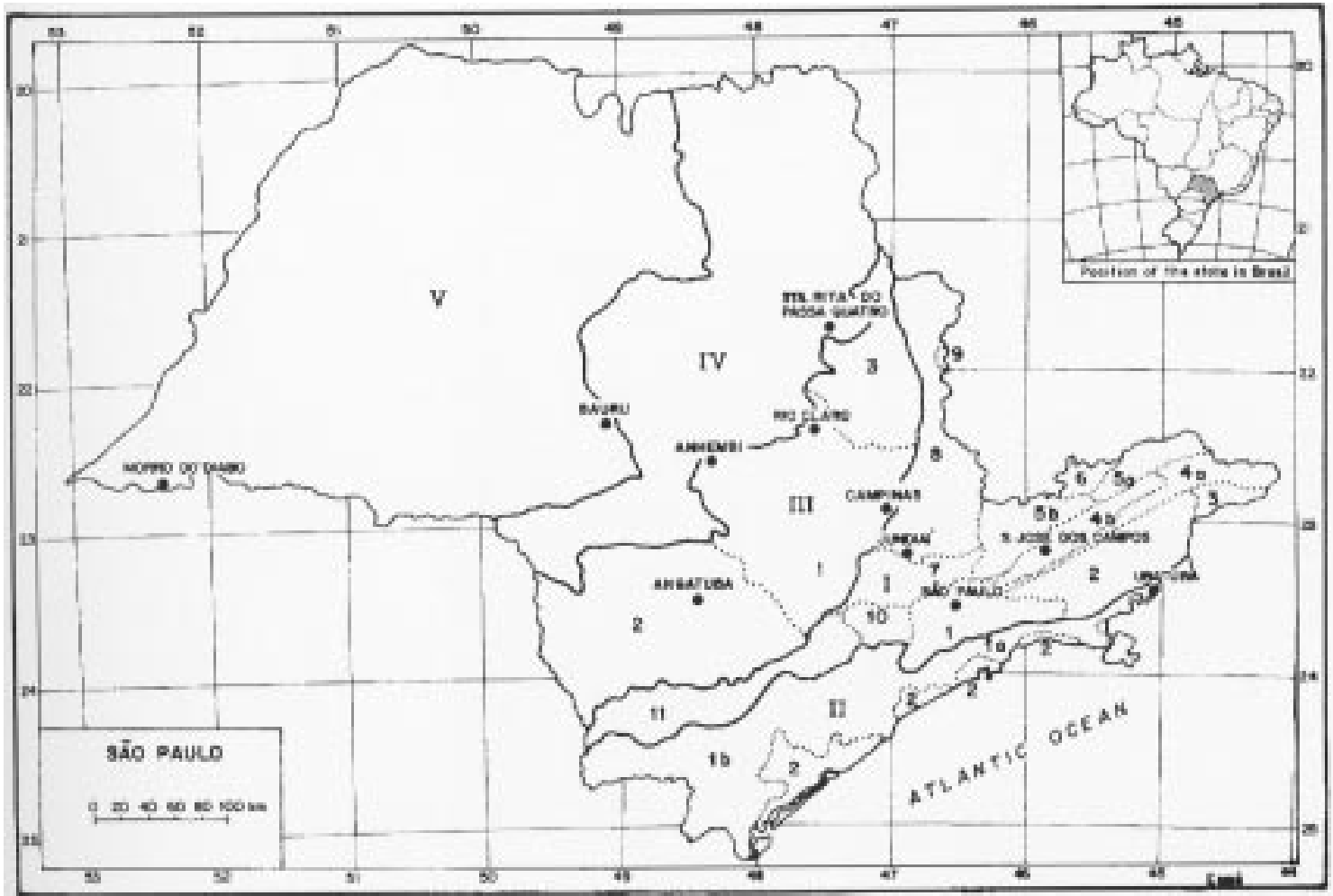

Figure 1. Localization of the municipalities where the forests were surveyed in the state São Paulo, southeastern Brazil. The geomorphologic compartments are: I) Atlantic plateau: I.1) Paulistan plateau, I.2) River Paraitinga plateau, I.3) Bocaina plateau; I.4) River Paraíba medium valey - I.4.a) Cristalin hills, I.4.b) Taubaté basin; I.5) Mantiqueira mountain ridge - I 5.a) Oriental, I.5.b) Occidental; I.6) Campos do Jordão plateau, I.7) São Roque mountain ridge, I.8) North cristalin zone, I.9) Poços de Caldas plateau, I.10) Ibiúna plateau, I.11) Occidental cristalin plateau. II) Coastal province: II.1) Coastal mountain ridge - II.1.a) Serra do Mar, II.1.b) Serra do Paranapanema; II.2) Littoral lowlands. III) Peripheral depression: III.1) Medium river Tietê zone, III.2) River Paranapanema zone, III.3) River Moji Guaçu zone. IV) Basaltic "cuestas". V) Occidental plateau. (After Almeida, 1964). 
Table 1. Samples included in this study (numbers 1 to 13), the municipalities and the geomorphological compartments (in parenthesis, see figure 1) in which they were surveyed, authors that surveyed them, and the methods employed. Incl. means the criteria used to include the individuals in the sample, and, unless otherwise specified, means the diameter at breast height. Capital letters outside parentheses indicate vegetation types according to Chiarini \& Coelho (1969): TBF -tropical broadleaf forest, STBF - semideciduous tropical broadleaf forest, ASTF - high-altitude subtropical forest, HTB - humid tropical broadleaf forest of slopes.

\begin{tabular}{lllll}
\hline Municipality & Localization & Methods & Incl. & Authors \\
\hline Angatuba & 1) State Reserve (III.2) TBF & Floristics & Trees & Torres, 1989 \\
Anhembi & 2) Barreiro Rico Farm (III.1)TBF & Floristics & Trees & Assumpção et al., 1982 \\
Bauru & 3) State Rescrve (V)STBF & Quarters & $10 \mathrm{~cm}$ & Cavassan et al., 1984 \\
Campinas & 4) Jequitibás Woodland (III.1)TBF & Census & Trees & Matthes et al., 1988 \\
Jundiaí & 5) Japi Municipal Reserve (1.7)TBF & Plots & $5 \mathrm{~cm}$ & Rodrigues et al., 1989 \\
Rio Claro & 6) S. José Farm (III.1)TBF & Quarters & $130 \mathrm{~cm}^{1}$ & Pagano \& Leitão F., 1987 \\
Sta. R. P. Quatro & Vaçununga State Park (IV)TBF & & & \\
& 7) Capetinga Stand & Quarters & $15 \mathrm{~cm}^{2}$ & Martins, 1979, 1991 \\
S. J. Campos & 8) Praxedes Stand & Plots & $10 \mathrm{~cm}$ & Bertoni et al., 1988 \\
São Paulo & 10) IBt Ipiranga Fountains State Park (I.1)TBF & Quarters & $5 \mathrm{~cm}$ & De Vuono, 1985 \\
& 11) USP S. Paulo Universitary Campus (I.l)TBF & Floristics & Trees & Rossi,1987 \\
Teodoro Sampaio & 12) Morro do Diabo State Park (V)SDTBF & Floristics & Trees & Baitello et al., 1988 \\
Ubatuba & 13) Agronomic Experimental Station (II.1.A) HTB & Quarters & $10 \mathrm{~cm}$ & Silva \& Leitão F., 1982 \\
\hline
\end{tabular}

Sta. = Santa; R. = Rita do; P.= Passa; S.= São; J.= José dos; Quarter = quarter method (Cottam \& Curtis 1956); (1) stem height; (2) perimeter at ground level; F. = Filho.

Table 2. Principal abiotic features of the samples studied in the state of São Paulo, southeastern Brazil. Altitude figures represent the median of the altitudinal amplitude in each sample. Yearly rain figures are average totals, and the values between parentheses refer to standard deviation

\begin{tabular}{lcccccc}
\hline Samples & $\begin{array}{c}\text { Number of } \\
\text { Species }\end{array}$ & Altitude $(\mathrm{m})$ & Yearly Rainfall (mm) & Soil Type & Nutrition & Texture \\
\hline Angatuba & 176 & 900 & 1450 & Li & $\mathrm{d}$ & sandy \\
Anhembi & 76 & 500 & $1338(212)$ & AQ & $\mathrm{a}$ & sand \\
Bauru & 60 & 570 & $1281(276)$ & LR/LVE & $\mathrm{e}$ & sandy \\
Campinas & 178 & 665 & 1365 & LVA & $\mathrm{e}$ & sandy \\
Capetinga & 92 & 610 & $1526(329)$ & LR & $\mathrm{e}$ & clayey \\
IBt & 182 & 798 & 1318 & LVA s & $\mathrm{a}$ & sandy \\
Japi & 128 & 1020 & 1400 & LVA s & $\mathrm{d}$ & sandy \\
M. Diabo & 113 & 300 & 1100 & LVE & $\mathrm{a}$ & sandy \\
Praxedes & 73 & 640 & $1526(329)$ & LR/LVE & $\mathrm{d}$ & clay-loam \\
Rio Claro & 155 & 630 & 1360 & LVA & $\mathrm{e}$ & sandy \\
S. J. Campos & 195 & 840 & 1400 & LVA s & $\mathrm{a}$ & clay-loam \\
Ubatuba & 123 & 105 & $2377(145)$ & LVA s & a & sandy-clay \\
USP & 90 & 750 & 1428 & LVA s & $\mathrm{d}$ & sandy-clay \\
\hline
\end{tabular}

M. = Morro do; S.J. = São José dos; Li = Litholic soil; AQ = Quartz Sand; LR = Dusky Red Latosol; LVE = Dark-Red Latosol; LVA $=$ Yellow-Red Latosol; $\mathrm{d}=$ dystropphic $($ acid); $\mathrm{a}=$ allic $($ dystrophic); $\mathrm{e}=$ eutrophic; $\mathrm{s}=$ shallow fase .

months/year) and present a variable frost occurrence (up to 6 days/year, in average). These two floristic blocks may be called hygrophyllous (group 1) and mesophyllous (group 2), respectively.

Two floristic groups can be distinguished in the mesophyllous block at the level of about $11 \%$ : one high-altitudinal (group 3), occurring from $750 \mathrm{~m}$ to $1,020 \mathrm{~m}$ of median altitude above sea level, where the average frequency of frost is greater than 3 days per year; the other, low-altitudinal (group 4) occurring at median altitudes ranging from $105 \mathrm{~m}$ to $665 \mathrm{~m}$, where the average frequency of frost is less 


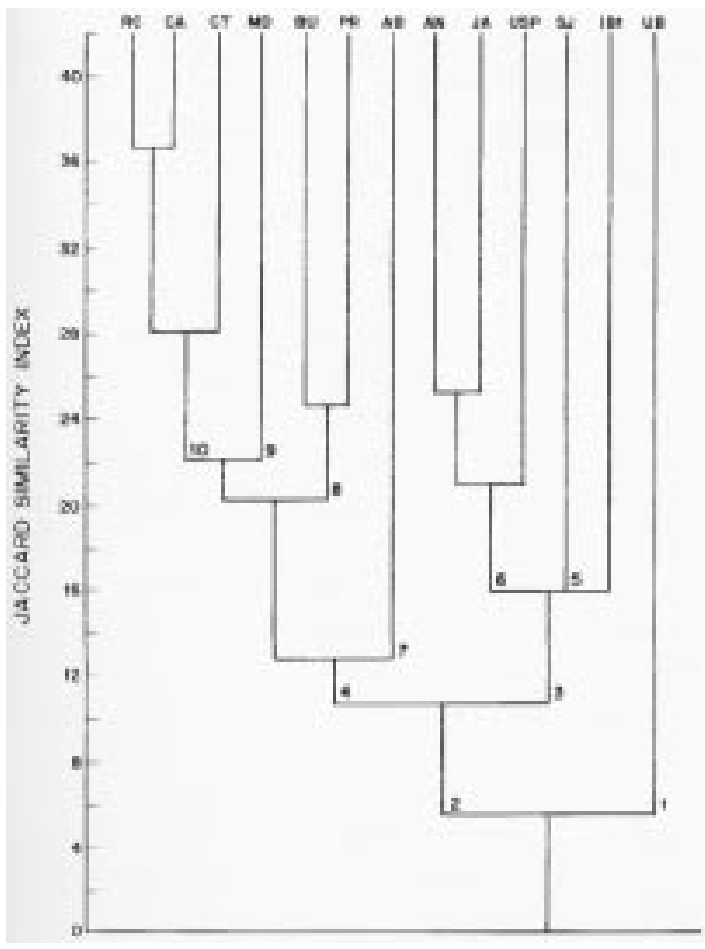

Figure 2. Species binary similarity phenogram of forests of the state of São Paulo, southeastern Brasil: RC = Rio Claro, $\mathrm{CA}=$ Campinas, $\mathrm{CT}=$ Capetinga (Santa Rita do Passa Quatro), $\mathrm{MD}=$ Morro do Diabo (Teodoro Sampaio), BU = Bauru, $\mathrm{PR}=$ Praxedes (Santa Rita do Passa Quatro), AB = Anhembi, AN = Angatuba, JA = Japi (Jundiaí), USP = Universitary campus (São Paulo), SJ = São José dos Campos, IBt = Instituto de Botânica (São Paulo), $\mathrm{UB}=$ Ubatuba. Numbers refer to groups commented in the text.

than 3 days/year, often less than 1 day/year (Nimer 1977).

All the samples in the mesophyllous high-altitudinal f1oristic group occur on dystrophic soils. Dystrophic soils have the cation exchange capacity with less than $50 \%$ saturation by bases. In the dystrophic soils most of the cation exchange capacity may be due either to exchangeable alluminum (the soil is said to be allic), or to protons (the soil is said to be acid). The mesophyllous high-altitudinal floristic group may be thus subdivided in a subgroup on allic soils (group 5: São José dos Campos and IBt) and another on acid soils (group 6: Angatuba, Japi and USP).

The mesophyllous low-altitudinal f1oristic block splits into a group on a Quartz Sand soil (Anhembi - group 7) and another on Latosols (Rio Claro,

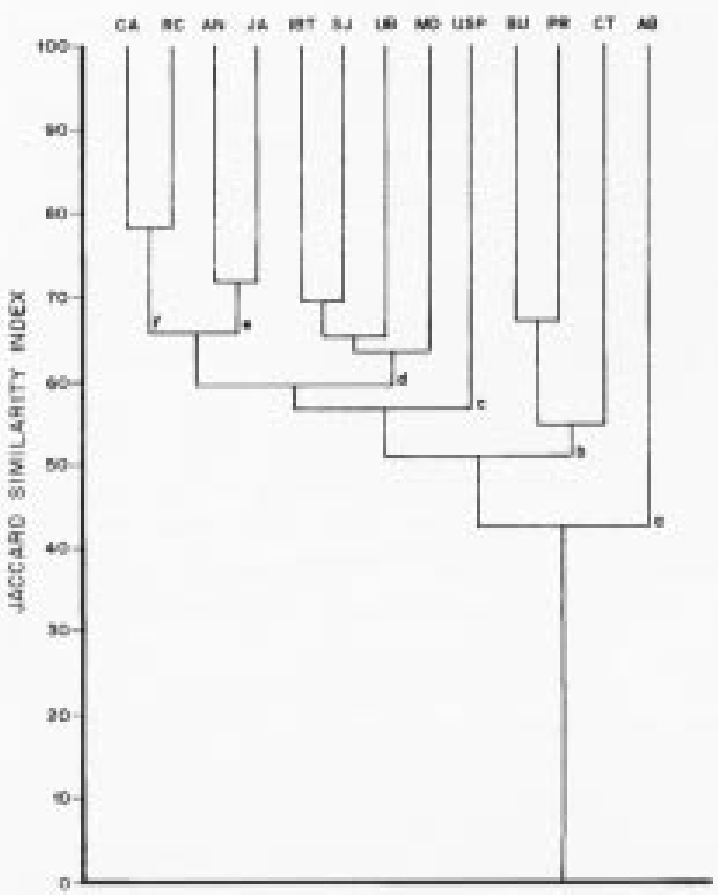

Figure 3. Family binary similarity phenogram of forests of the state of São Paulo, southeastern Brasil: CA = Campinas, $\mathrm{RC}=$ Rio Claro, AN = Angatuba, JA = Japi (Jundiaí), IBt = Instituto de Botânica (São Paulo), SJ = São José dos Campos, UB = Ubatuba, $\mathrm{MD}=$ Morro do Diabo (Teodoro Sampaio), USP $=$ Universitary campus (São Paulo), BU = Bauru, $\mathrm{PR}=$ Praxedes and $\mathrm{CT}=$ Capetinga (both in Santa Rita do Passa Quatro), AB = Anhembi. Small letters refer to groups commented in the text.

Campinas, Capetinga, Morro do Diabo, Bauru and Praxedes). The latter group shows a subgroup on a soil association of Dark-Red with Dusky-Red Latosols (Bauru and Praxedes - group 8) and another on Latosol units (Rio Claro, Campinas, Capetinga and Morro do Diabo). This last subgroup shows a division of one sample (Morro do Diabo - group 9) on dystrophic allic Yellow-Red Latosol and three samples (Rio Claro, Campinas and Capetinga group 10) on eutrophic Latosols. Rio Claro and Campinas are samples on sandy Yellow-Red Latosol, while Capetinga is on a very clayey Dusky-Red Latosol.

The family similarity (figure 3 ) presents some resemblance with the specific similarity, but also presents some differences. Differences are expected to occur because the family level is at a much more 
inclusive taxonomic hierarchy, including species with different growth forms and distinct ecological preferences. Therefore, it is also expected that a similarity pattern at the family leveI will be much more difficult to explain than at the species level.

The family similarity pattern shown by figure 3 is not likely to have any relation to the climate or to altitudinal variations or to the average frequency of frost. Moreover, the high values of similarity in figure 3 may be interpreted as an indication of only one family block for all forests compared. This situation implies in that the recognition of family groups is rather artificial, and the attempt to relate them to abiotic feature is quite inappropriate. However, bearing in mind all these limitations, it is possible to recognize some coherences. Anhembi (group a) occurs on a soil with a very sandy (over $90 \%$ ) texture, detaching from all other samples at the $42 \%$ similarity level (figure 3 ) which do not show a so high sand content. This separation is coherent with the species similarity pattern opposing groups 7 and 8 of figure 2. By consulting the primary binary matrix it is possible to point out Magnoliaceae, Polygonaceae and Violaceae as examples of families occurring preferably on Quartz Sand soil.

At the level of about $51 \%$ similarity a group of samples (Bauru, Praxedes, and Capetinga - group b) detaches from the others. This group occurs on Dusky-Red Latosol and associations of Dusky-Red and Dark-Red Latosol which have very high iron content. Urticaceae and Phytolacaceae are families occurring preferably on these soils. It is possible to point out four other groups: c) USP, d) IBt, São José dos Campos, Ubatuba and Morro do Diabo, e) Angatuba and Japi, and f) Campinas and Rio Claro. The position of group $\mathrm{c}$ is hard to explain, Cecropiaceae, Oleaceae, and Piperaceae being its preferencial families. Group d occurs on allic soils, with Caricaceae, Guttiferae, and Tiliaceae as its preferencial families. Group e occurs on acid soils, with Cunoniaceae, Dilleniaceae, and Ternstroemiaceae as preferencials. Group f occurs on eutrophic soils, showing Bombacaceae and Polygonaceae as preferencials.

\section{Discussion}

It is possible to synthesize climatic and edaphic features by means of the thermohydric soil regimes such as proposed by USDA (1973). Figure 4 presents a preliminary map of these regimes for the soils of the state of São Paulo, based on Oliveira et al. ( 1976). There is a high degree of correspondence when the species similarity pattern is considered: the hygrophyllous block occurs on soil with a hyperthermic perudic regime; the high-altitudinal mesophyllous block occurs on soils with a thermic udic regime; and the low-altitudinal mesophyllous block occurs on soils with a hyperthermic udic regime. However, the correspondence is very weak when the family similarity pattern is considered.

Also there is no correspondence between the dendrograms (figures 2 and 3 ) and the geomorphological compartmentation of the state of São Paulo (figure 1). This may suggest that, although each major compartment was formed in a different geological time (Almeida 1964), the abiotic conditions have stayed reasonably stable during a period of time long enough for the tree species be distributed as they are presently. For this reason the interpretation of the similarity patterns is here made within an uniformitarianistic way (Wiegleb 1989).

Different sampling methods and including criteria were employed by the different authors to survey the stands considered here, which also present very different floristic richness and successional stages. However, these differences seem not to have influenced the results, for the phenograms do not group together samples surveyed by means of the same method. This may be an indication that at least a representative sylvatic unit (Torquebiau 1986) was included in each sample, and that successional tree species are different according to different regional abiotic features.

The floristic repartition in the forests of the state of São Paulo seems to be conditioned by different factors. At the species level the climate divides the most inclusive floristic blocks, the hygrophyllous and the mesophyllous. The tota1 amount of rainfall and its distribution along the year as well as the average frequency of frost seem to be the most important conditioners of this first division. The hygrophyllous block would correspond to the humid tropical broadleaf forest of slopes of Chiarini \& Coelho (1969). However, only one sample is not sufficient to corroborate the homogeneity of that floristic block, and other surveys should be considered in a future analysis. Siqueira (1994) 


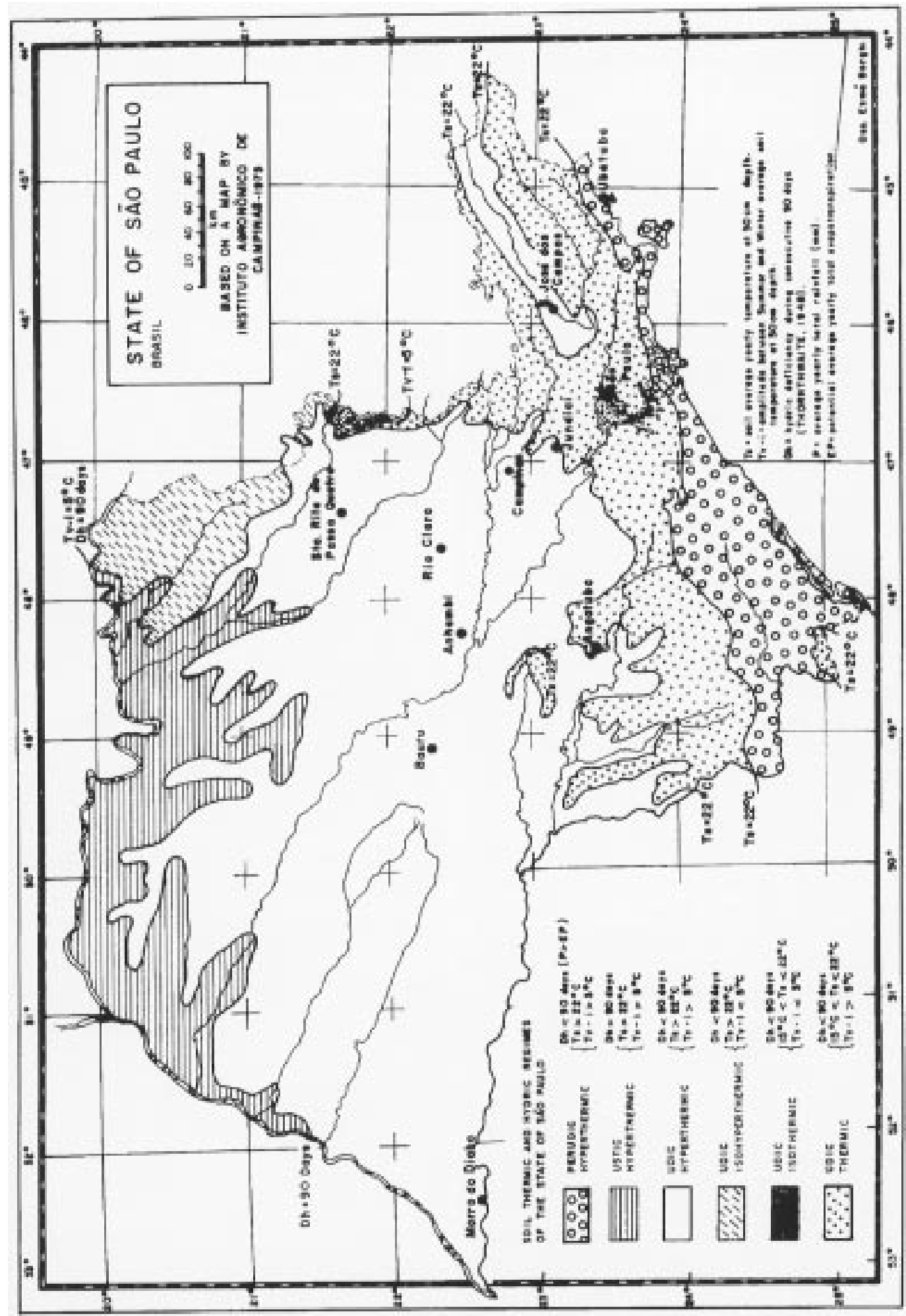

Figure 4. Hydric and thermic regimes of soils in the state of São Paulo, southeastern Brazil, based on Oliveira et al. (1976). 
made an extensive study of the Atlantic Forest of Slope in Brasil and found a pattern that indicates an influence of both the distance from the sea and altitude. This could be interpreted as different rainfall and air-humidity regimes and variable frequency of frost. The influence of altitude found by Siqueira (1994) produced a pattern similar to that found in our study for the mesophyllous floristic group.

The median of altitude divides the mesophyllous floristic block in a high-altitudinal group (above $750 \mathrm{~m}$ ) and a low-altitudinal group (below $700 \mathrm{~m}$ ). The division of the interior Paulian forests in two tree species groups around $700 \mathrm{~m}$ altitude was also obtained by Salis et al. (1995). The division in high-altitudinal and low-altitudinal floristic groups coincides with the subtropical and tropical forest types of Chiarini \& Coelho (1969), respectively. However, the high-altitudinal mesophyllous floristic group seems to occupy a surface greater than the one mapped by those authors, including areas attributed by them to the broadleaf tropical forest. The low-altitudinal mesophyllous floristic group does not show the division into broadleaf tropical forest and semideciduous broadleaf tropical forest claimed by those authors. The absence of surveys in the respective areas of occurrence did not permit a test of whether there are floristic differences between Araucaria and Araucaria-Podocarpus mixed forests.

Soil parameters (like taxonomic category, eutrophism, allic or acid distrophism, iron content, texture), and disturbance degree and successional stage could be important modifiers, selecting the species which could compose the flora of each mesophyllous floristic group.

Climate and altitude do not seem to influence the spatial partition of the tree families in forests of the state of São Paulo. The same family may include species which could occur under different climates and different altitudes, within the range represented in the samples studied. Although very weak, there is an indication of the soil nutritional status as a possible constraint to the spatial partition of botanical families in forests of the state of São Paulo.

The alpha-diversity figures of the Paulian forests are at the same order of those of the Amazonian "terra firme" forests (Martins 1989). The mathematical complement of the similarity can give an idea of the magnitude of the beta-diversity (Pielou 1975). Therefore, by considering the low species similarity of the forests compared, it can be said that they have also high beta-diversity. MuellerDombois \& Ellenberg (1974) stated that two plant communities may be considered similar when the binary Jaccard's Index has a value of at least $25 \%$. Thus, the low similarity among the specific blocks could be a strong indicative of real floristic separation in the field. However, at the family level the similarity is very high, and it is possible to consider it an indicator of only one family block in all forests compared. Considering these high diversities, it is urgent that the present environmental policy be put in practice immediately, and legal devices be created, in order to maximize the conservation of the still existing biodiversity in the state of São Paulo.

Explanation and confirmation are two modes used to face observable phenomena with theory (Pickett \& Kolasa 1989). It must be kept in mind that a coherent explanation of the similarity patterns found does not mean that the hypotheses are correct, but simply that they have some degree of probability. These probabilities should be evaluated by means of confirmation (Pickett \& Kolasa 1989). New analyses using a greater number of samples and considering the phytocenotic organization of forests of the state of São Paulo and also of other states will certainly furnish results and hypotheses which can corroborate, modify or deny the explanation presented in this paper.

Acknowledgements - The authors thank the Fundo de Apoio ao Ensino e à Pesquisa da UNICAMP (FAEP/UNICAMP process 024/86), the Fundação de Amparo à Pesquisa do Estado de São Paulo (FAPESP - process 86/2906-8) and the Conselho Nacional de Desenvolvimento Científico e Tecnológico $(\mathrm{CNPq}$ - process 40-1223/87.6/ZO/FV) for the financial support, Dr. Grady Linder Webster (Section of Ecology and Evolution/Division of Biological Sciences/University of California, Davis, USA) for the critical reading of the manuscript, and Esmeralda Zanchetta Borghi for the drawings.

\section{References}

ALMEIDA, F.A.de. 1964. Fundamentos geológicos do relevo paulista. Série teses e monografias 14. Instituto de Geografia/USP, São Paulo.

ASSUMPÇÃO, C.T., LEITÃO FILHO, H.de F. \& CESAR, O. 1982. Descrição das matas da fazenda Barreiro Rico, estado de São Paulo. Revta brasil. Bot. 5:53-66. 
AZEVEDO, A. de. 1950. Regiões clímato-botânicas do Brasil. Bolm paulista Geogr. 6:32-43.

BAITELLO, J.B., PASTORE, J.A., AGUIAR, O. T., SÉRIO, F.C. \& SILVA, C.E. F. 1988. A vegetação arbórea do Parque Estadual do Morro do Diabo, município de Teodoro Sampaio, estado de São Paulo. Acta bot. brasilica 1(Suplemento):221-230.

BERTONI, J.E.de A., MARTINS, F.R., ,MORAES, J.L.de \& SHEPHERD, G.J. 1988. Composição florística e estrutura fitossociológica do Parque Estadual de Vaçununga, Santa Rita do Passa Quatro, SP - gleba Praxedes. Bolm Téc. IF 42:149-170.

CAMARGO, M.N., KLAMT, E. \& KAUFFMAN, J.H. 1987. Classificação de solos usada em levantamentos pedológicos no Brasil. Bolm inf. SBCS 12:11-33.

CAMPOS, G. de. 1912. Mappa florestal. Directoria do serviço de estatística do ministério da agricultura, indústria e commercio, Rio de Janeiro.

CAVASSAN, O., CESAR, O. \& MARTINS, F.R. 1984. Fitossociologia da vegetação arbórea da Reserva Estadual de Bauru, estado de São Paulo. Revta brasil. Bot. 7:91-106.

CHIARINI, J.V. \& COELHO, A. G. de S. 1969. Cobertura vegetal natural e áreas reflorestadas no estado de São Paulo. Instituto Agronômico, Campinas.

CLIFFORD, H.T. \& STEPHENSON, W. 1975. An introduction to numerical classification. Academic Press, New York.

COTTAM, G. \& CURTIS, J.T. 1956 The use of distance measures in phytosociological sampling. Ecology 37:451-460.

CRONQUIST, A. 1981. An integrated system of classification of flowering plants. Columbia University Press, New York.

DE VUONO, Y.S. 1985. Fitossociologia do estrato arbóreo da floresta da Reserva Biológica do Instituto de Botânica (São Paulo, SP). Tese de doutorado, Universidade de São Paulo, São Paulo

EITEN, G. 1970. The vegetation of the state of São Paulo. Boletim 7. Instituto de Botânica, São Paulo.

FERRl, M. G. 1980. Vegetação brasileira. EDUSP, São Paulo; Itatiaia, Belo Horizonte.

GAUCH JR.,H.G. 1982. Multivariate analysis in community ecology. Cambridge University Press, Cambridge.

HEYWOOD, V.H. 1967. Plant taxonomy. Studies in biology 5. Edward Arnold Publishers, London.

LOEFGREN, A. 1898. Ensaio para uma distribuição dos vegetaes nos diversos grupos florísticos no estado de São Paulo. Boletim 11. Commissão Geographica e Geologica de São Paulo, São Paulo.

MARTINS, F.R. 1979. O método de quadrantes e a fitossociologia de uma floresta residual do interior do estado de São Paulo: Parque Estadual de Vaçununga. Tese de doutorado, Universidade de São Paulo, São Paulo.

MARTINS, F.R. 1989. Fitossociologia de florestas do Brasil: um histórico bibliográfico. Pesquisas, série Botânica, 40:102-164.

MARTINS, F.R. 1991. Estrutura de uma floresta mesófila. Editora da UNICAMP, Campinas.

MARTIUS, C.F.P. von. 1840. Tabulae physiognomicae. Brasiliae regionis iconibus expressae. In Flora brasiliensis. (C.F.P. von Martius, S. Endlicher, A.G. Eichler e J. Urban, eds). Lipsaea apud Frid. Fleischer in Comm., Munich. V.1, Tomus 1, p.1-110.

MATTHES, L.A.F., LEITÃO FILHO, H. de F. \& MARTINS, F.R. 1988. Bosque dos Jequitibás (Campinas, SP): composição florística e fitossociologia do estrato arbóreo. In Anais do V Congresso da Sociedade botânica de São Paulo, Botucatu, p.55-76.
MUELLER-DOMBOIS, D. \& ELLENBERG, H. 1974. Aims and methods of vegetation ecology. Wiley, New York.

NIMER, E. 1977. Clima. In Geografia do Brasil (IBGE, ed.). Fundação Instituto Brasileiro de Geografia e Estatística, Rio de Janeiro. V.3. Região Sudeste, p.51-89.

OLIVEIRA, J.B. de, ALFONSI, R.R. \& PEDRO JR, M.J. 1976. Regimes hídricos e térmicos dos solos do estado de São Paulo. In Anais do XV Congresso brasileiro de ciência do solo. Sociedade brasileira de ciência do solo, Campinas p.359-362.

PAGANO, S.N. \& LEITÃO FILHO, H.de F. 1987. Composição florística do estrato arbóreo de mata mesófila semidecídua no município de Rio Claro (estado de São Paulo). Revta brasil. Bot. 10:37-47.

PICKETT, S.T.A. \& KOLASA, J. 1989. Structure of theory in vegetation science. Vegetatio 83:7-15.

PIELOU, E.C. 1975. Ecological diversity. Wiley, New York.

PIELOU, E.C. 1984. The interpretation of ecological data. A primer on classification and ordination. Wiley, New York.

RODRIGUES, R.R., MORELATO, L.P.C., JOLY, C.A. \& LEITÃO FILHO, H.de F.1989. Estudo florístico e fitossociológico em um gradiente altitudinal de mata estacional mesófila semidecídua na serra do Japi, Jundiaí. Revta brasil. Bot. 12:71-84.

ROSSI, L. 1987. A flora arbóreo-arbustiva da mata da reserva da Cidade Universitária Armando de Salles Oliveira, São Paulo, SP. Dissertação de mestrado, Universidade de São Paulo, São Paulo.

SALIS, S.M., SHEPHERD, G.J. \& JOLY, C.A. 1995. Floristic comparison of mesophytic semideciduous forests of the interior of the state of São Paulo, Southeast Brazil. Vegetatio 119:155-164.

SAMPAIO, A.J.de. 1945. Fitogeografia do Brasil Companhia Editora Nacional, São Paulo.

SILVA, A.F.da. 1989. Composição florística e estrutura fitossociológica do estrato arbóreo da Reserva Florestal Professor Augusto Ruschi, São José dos Campos, SP. Tese de doutorado, Universidade Estadual de Campinas, Campinas.

SILVA, A.F.da \& LEITÃO FILHO, H.de F. 1982. Composição florística e estrutura de um trecho da mata atlântica de encosta no município de Ubatuba (São Paulo, Brasil). Revta brasil. Bot. 5:43-52.

SILVA, A.F.da \& SHEPHERD, G.J. 1986. Comparações florísticas entre algumas matas brasileiras utilizando análise de agrupamento. Revta brasil. Bot. 9:81-86.

SIQUEIRA, M.F.de 1994. Análise florística e ordenação de espécies arbóreas da mata atlântica através de dados binários. Tese de mestrado, Universidade Estadual de Campinas, Campinas.

THORNTHWAITE, C.W. 1948. An approach towards a rational classification of climate. Geogr. Rev. 38:55-94.

TORQUEBIAU, E.F. 1986. Mosaic pattern in dipterocarp rain forest in Indonesia, and their implications for practical forestry. J. Trop. Ecol. 2:301-325.

TORRES, R.B. 1989. Estudos florísticos em mata secundária da Estação Ecológica de Angatuba, Angatura (São Paulo). Tese de mestrado, Universidade Estadual de Campinas, Campinas.

USDA. United States Department of Agriculture. 1973. Soil taxonomy. A basic system for soil classification for making and interpreting soil surveys. Washington.

WIEGLEB, G. 1989. Explanation and prediction in vegetation science. Vegetatio 83:17-34. 